UDC $316.47+314.4$

DOI: $10.21668 /$ health.risk/2018.3.17.eng

Read

online

\title{
SOCIAL CAPITAL AS A FACTOR THAT CONTRIBUTES INTO POPULATION HEALTH: ANALYTICAL REVIEW
}

\author{
N.A. Lebedeva-Nesevrya ${ }^{1,2}$, S.Yu. Eliseeva ${ }^{2}$ \\ ${ }^{1}$ Federal Scientific Center for Medical and Preventive Health Risk Management Technologies, 82 Monastyrskaya Str., \\ Perm, 614045, Russian Federation \\ ${ }^{2}$ Perm State University, 15 Bukireva Str., Perm, 614990, Russian Federation
}

The paper contains a review of both domestic and foreign scientific works that focus on influence exerted by social capital on population health. The authors describe different approaches to interpretations of social capital as an attribute of an individual or a social group. At an individual level, different types of social capital are shown to influence a person's health via his or her involvement into a social group; this social group minimizes adverse effects produced by stress factors (a case in which we can speak about a social capital that "unites") and provides resources necessary to solve health-related problems (here we speak about a social capital that "brings us together"). The authors highlight that social capital and a social status which an individual or a social group has are interdependent.

At a group level, social capital is a mechanism that influences an individual's behavior as regards his or her health. A group can set certain models for health-preserving behavior and apply informal sanctions in case an individual's behavior is deviant thus reducing health risks. The authors also showed that health-related information tended to spread faster among those groups in which social capital was quite high. At a country level, social capital makes citizens to actively solve health-related problems and, consequently, determines activities performed by the state and aimed at providing citizens' safety and well-being. The authors also give special attention to a negative effect produced by group social capital, namely spread of risky behavioral practices within "poorly developed" social groups.

The paper gives two viewpoints on contributions made by individual and group social capital into formation of health. The first one states that direct contacts are more important for an individual than his or her civic stand as the latter depends on a personal psychological type. The second viewpoint is that individual social capital can be a significant health factor only when it is included into a group with high social capital. The authors think it is very important to understand how significant social capital is for determining health as such understanding will help to develop new approaches to creation of conditions that are favorable for preservation of citizens' health.

Key words: social capital, social risk factors, social determinants, social networks, health.

In 2015 the UN member states adopted Sustainable Development goals that were to be achieved by 2030; these goals are in many ways related to population health and most of them are aimed at resisting social factors that cause health risks. If they are achieved, it will lead to a decrease in a number of people who have low social status that means unfavorable living conditions, limited access to healthy nutrition and drinking water; it will help to raise adherence to a healthy lifestyle and rational consumption and to develop infrastructure for physical training and recreation etc. [1]. The WHO experts spoke about the significance of social factors for human health on the World Conference on Social Determinants of Health held in 2011. They highlighted the necessity to improve conditions of people's everyday life and to provide equal access to health-preserving resources for everybody [2].

(C) Lebedeva-Nesevrya N.A., Eliseeva S.Yu., 2018

Natalya A. Lebedeva-Nesevrya - Doctor of Sociological Sciences, Associate Professor, Head of Laboratory for Social Risks Analysis Techniques, Professor at Sociology Department (e-mail: natnes@ fcrisk.ru; tel.:+7 (342) 237-25-34).

Sofya Yu. Eliseeva - a student attending the 2nd year of studies for a Master of Sociology degree (e-mail: sonia.eliseeva@bk.ru; tel.:+7 (342) 239-63-29). 
Experts have been discussing a leading role that belongs to socioeconomic (low income and poor education) and behavioral (smoking, alcohol abuse, poor physical activity, improper nutrition, and unsafe sexual behavior) factors in determination of an individual's health since 70ties last century; these discussions can be found in scientific works that have been published starting from that period of time [3-8]. Besides, they have repeatedly mentioned a role played by macrosocial contexts (technological development of a country, its political regime, migration intensity etc.) in formation of socially determined etiologies [9, 10]. A new concept, "social capital", appeared and was integrated in the discourse on social determination of health in late 1990s. On one hand, it can be explained by popularization of social capital theory in works by J.S. Coleman [11] and R.D. Putnam [12] published at that time. On the other hand, there was a necessity for public healthcare systems in the developed countries to search for new solutions to challenges associated with inequality in the healthcare.

In spite of almost 30 years devoted to research on a correlation between social capital and health, the issue is still being discussed due to the fact that there is no unified view on the essence and structural components of social capital. It is primarily related to its interpretation either as an individual's attribute (this approach was first formulated in works by P. Bourdieu [13]) or as an attribute of a social group (interpretation by R.D. Putnam [14]).

Individual social capital is an ability of a person to benefit from his or her affiliation with various social networks [15]. Individuals are assumed to "invest" into social networks in order to gain "a return in a form of instrumental acts" [16]. Relations between those who participate in social relations are converted into various resources (money, reputation, power, information etc.), and in case of necessity individuals, via their strong or weak connections in various social networks, are able to either mobilize these resources available to them in social networks [17], or use their own resources more efficiently with the help of their social connections [18]. A size of individual social capital is determined by an individual's social status, his or her position in a social network and a purpose of an interaction (instrumental or expressive one) [19]; and possibilities to accumulate this capital depend on interiorized standards, strong social unity, or its orientation at reciprocity [15].

Social capital as an attribute of a group or a society as a whole means that if a society (existing on a specific territory, in region or a country) has high collective social capital, then even individuals with low individual social capital can somehow benefit from it (they are also "beneficiaries") [20]. Social capital at a group level has two dimensions, a structural one (social networks that are formalized to a various extent), and a cultural one (common standards that are shared by all members of a social network and that secure trust existing between interaction participants) [21]. Standards created within a group (including reciprocity) are generalized and then applied to a society as a whole thus making it more united and raising its solidarity [14]. Trust is a significant measure of social capital at a society level; here we mean generalized interpersonal trust ("people in general") and institutional one [22]. Results of trust measuring gave grounds for a significant number of empirical research on social capital [23-26].

And how is social capital related to individual and public health? We can offer several explanations at an individual level. First of all, if a person is involved into social networks (family, friends, occupational and confessional ones, etc.), it provides him or her with various social support (emotional, instrumental, evaluative, and informative one) [27]. This support can be a "buffer" that minimizes adverse effects produced by stress factors [28]. An action mechanism of such a "buffer" is "reevaluation" of stress, a decrease in a stress factor significance, wider range of possible ways to solve a problem, stronger coping strategies, changes in individual's moods, etc. [29, 30]. A classic "Roseto effect" can be found exactly in high intra-group support; this effect explained significantly lower mortality caused by cardiovascular diseases in Roseto, an American-Italian town (Pennsylvania, the USA), in comparison with its neighbor town Bangor in 1935-1965 [31]. Secondly, involvement into social networks gives an individual a possibility to use material and organizational resources available in this or that network [32]. We can illustrate it with an example of individuals resorting to 
"social relations chains" in case of health problems [33] when they try to find better medical experts; it often happened in the USSR and still happens now. The third explanation is related to interdependence between social capital and an individual's social status where having the former leads to an increase in the latter which, in its turn, means an access to qualitative nutrition, sport and recreational infrastructure, safe housing, and qualified medical services [34]. Besides, high social status creates a "positive feeling of being a select one" and leads to a decrease in stress [35].

High individual social capital is often combined with high socioeconomic status and health [36] and it is explained with such mediator categories as "healthy lifestyle" and "selfpreserving behavior". Thus, research conducted in the UK and Sweden revealed that individuals with high socioeconomic status and "strong" social capital tended to consume healthy nutrition that included a lot of fruit and vegetables [37, 38]. There are some works that dwell on the analysis of correlation between neighborhood socioeconomic status, social capital, and health: their authors conclude that people who live in wealthy neighborhood and who obviously already have a certain social status also enjoy a better opportunity to invest into social networks development [39]. "Wealthy" districts are safer and, consequently, people who live there (especially children and elderly people) can meet each other more frequently and do things together; therefore, they have better opportunity to accumulate social capital and to use it to improve their health [40]. At the same time, research that focused on poor districts revealed that people who lived there could also be involved into social networks with great trust between participants, unity, and readiness to provide mutual support, that is, they could also have certain social capital in spite of their low socioeconomic status [41].

Various types of individual social capital are not equally involved into producing effects on health. As social capital at an individual level reflects a person's involvement into social networks, it is usually divided into "bonding" capital that describes relations between close relatives and friends, "bridging" capital that describes networks with weaker relations (colleagues or neighbors) [42], and "linking" capital [43] that describes vertical connections between people from various social strata. If a person has bonding social capital, it helps to get social support, while "bridging" or "linking" capital provide access to information or organizational resources.

If we consider social capital as a collective attribute, we can spot out two ways in which it can influence health. The first one is related to impacts exerted by social groups on individual health-related behavior. Such groups possess clear and shared standards for reciprocity (mutual support) and high level of trust; they set (or even dictate) certain behavioral standards and models to their members, including those related to health. A lot of empirical research performed by I. Kawachi, a professor at Harvard University, revealed that people who lived in local "neighborhoods" with strong social integration were more inclined to adhere to standards of self-preserving behavior declared by society leaders and approved by society members; in particular, they tended to more willingly attend their doctors bearing prevention in mind, and they more frequently went to parks and public gardens to relax [44]. Besides, strong group unity allows to apply informal sanctions efficiently in cases when group members pursue deviant behavioral patterns [45], thus lowering both individual and social health risks. Finally, if a group has high social capital, health-related information spreads faster within it, for example, information about environmental contamination hazards, new opportunities and innovations in the sphere of health preservation and improvement etc.

It is important to note that social capital has its negative effects; for example, they become apparent in groups with strong unity and adverse group standards (that contradict conventional ones). Risky behavioral practices (smoking, alcohol abuse, and unsafe sex) can be spread in such communities with the help of pressure exerted by a group and a certain lifestyle can be imposed upon its members [46].

The second way in which group social capital can influence health is related to civil involvement that is often called a social capital indicator [47, 48]. Groups with higher social capital are more likely to be socially active and 
ready to get themselves involved into decisionmaking processes in the health sphere. They are also more likely to show initiative, to participate in local projects aimed at preservation and improvement of health in a community [49]. At a country level, this correlation becomes apparent via a developed system of social control and public management [50]: the higher interpersonal trust and social solidarity in a society is, the more efficient institutions of social control are, and, consequently, the more socially-oriented is a state that provides better safety and welfare for its citizens.

Social capital at a community level is usually divided into a structural one that reflects a variety of social connections and interactions, and a cognitive one that describes a quality of these connections with a level of trust and "social harmony" [51] that means being ready to provide support and share resources [52]. There was a research based on data provided by the European Social Survey performed in 20082009; the research focused on health of people living in 28 European countries and levels of their structural and cognitive social capital. The research revealed that in postmodern countries trust exerted great influence on public health while in less developed ones systematic contacts with close friends and relatives had greater significance. It is explained by the fact that in postmodern countries active social policy is combined with developed public structures; therefore, people don't tend to seek support only among their closest friend and relatives, and, on the contrary, given high level of trust in a society, try to enter various associations and groups that consequently helps them improve their health [53].

A matter of principle here is a type of social capital that exerts the greatest influence on health. In 2013 experts from the National Scientific Research Institute for Public Health of the Russian Academy of Medical Sciences described a correlation between health and social capital as per data obtained in the course of research on global aging and health of the population in the RF over 2007-2010 (the sampling included 4,335 people) [54]. Health was self-estimated as per a 5-score scale which then was grouped into three categories: "very good and good", "satisfactory", and "bad and very bad". Social capital was measured via interpersonal trust and social activity. Parameters obtained for different socialdemographic groups were compared. Validity of discrepancies was estimated with Student's t-test. It was detected that a level of generalized trust influenced a sense of security an individual had and self-estimation of his or her health; the same is true for interpersonal trust, and if an individual doesn't have anyone whom he or she trusts unreservedly among his or her family or close friends, there is a greater probability that he or she will estimate his or her health as being bad. Finally the authors came to a conclusion that direct contacts had greater significance for an individual's health than the overall atmosphere in the society and participation in public organizations since the latter to a great extent depends on a personal psychotype.

In 2015 experts performed comparative research on influence exerted by cognitive social capital on self-estimation of a person's health and probability of depression in men and women in Sweden and Ukraine. The research revealed that there was a more apparent correlation between cognitive social capital and selfestimation of one's health in Sweden, moreover, a level of capital was also higher in that country [55]. Experts detected a statistically significant relationship between self-estimation of one's health and a level of institutional trust, as well as between probability of depression and not feeling sufficiently safe; the relationship was detected both for men and women in Sweden while in Ukraine it was true only for women.

British experts showed in their research that when both types of social capital, individual and collective ones, were simultaneously included into an analysis, it didn't exert any significant influence on health [37], while data obtained by Norwegian experts revealed that social capital was equally significant both at individual and collective level [56]. The Report issued by the WHO European Regional Agency and based on the analysis of data obtained in the course of the European Social Survey conducted in 2002 and 2004 in 21 country contains a conclusion that individual social capital can be a significant factor that influences an individual's health only when this individual is involved into social groups with high collective social capital [57]. 
Conclusion. Application of social capital category to analyze ways of preserving and improving population health in the contemporary world can yield good results. There are certain ways to improve health of people living on this or that territory via accumulation of social capital; they include development of local communities, an increase in their social activity and involvement into finding solutions to local problems, assistance to non-commercial organizations and involvement of representatives from different social groups into their activities.

Risk-communications in health sphere can be made more efficient and important information can be spread faster due to implementation of activities aimed at enhancing social connections between neighbors or employees of the same organization.
A better insight into a contribution made by collective social capital into determination of health calls for new approaches to development of modern cities where unavoidable processes of individuals' atomization should be slowed down by creating conditions for "strong communities" able to build up an environment that is the most favorable for preservation of citizens' health.

Funding. The work was completed with financial support provided by the RF Presidential Grant aimed at supporting young Russian Doctors of Science (Project No. MD-281.2017.6).

Conflict of interests. The authors state there is no conflict of interests

\section{References}

1. Tseli v oblasti ustoichivogo razvitiya [Goals in the field of sustainable development]. Official website of the United Nations. Available at: https://www.un.org/sustainabledevelopment/ru/sustainabledevelopment-goals/ (06.09.2018) (in Russian).

2. Sotsial'nye determinanty zdorov'ya: itogi Vsemirnoi konferentsii po sotsial'nym determinantam zdorov'ya (Rio-de-Zhaneiro, Braziliya, 2011 g.): doklad sekretariata [The social determinants of health: the outcome of the World Conference on Social Determinants of Health]. World Health Organization, 2011, $20 \mathrm{p}$. Available at: http://apps.who.int/gb/ebwha/pdf_files/EB130/B130_15-ru.pdf?ua=1 (09.09.2018) (in Russian).

3. Marmot M.G., Rose G., Shipley M., Hamilton P.J. Employment grade and coronary heart disease in British civil servants. Journal of epidemiology and community health, 1978, vol. 32, no. 4, pp. 244-249.

4. Whitehead M. Inequalities in health: the black report and the health divide. London, Penguin Books, 1992, 464 p.

5. Adler N.E., Stewart J. Preface to the biology of disadvantage: socioeconomic status and health. Annals of New York academy of sciences, 2010, vol. 1186, pp. 5-23. DOI: 10.1111/j.17496632.2009.05337.x

6. Allen J., Balfour R., Bell R., Marmot M. Social determinants of mental health. International review of psychiatry, 2014, vol. 26, no. 4, pp. 392-407. DOI: 10.3109/09540261.2014.928270

7. Braveman P., Gottlieb L. The social determinants of health: it's time to consider the causes of the causes. Public health reports, 2014, vol. 129, no. 2, pp. 19-31. DOI: 10.1177/00333549141291S206

8. Lisitsyn Yu.P., Zhuravleva T.V., Khmel' A.A. Iz istorii izucheniya vliyaniya obraza zhizni na zdorov'e [From the history of studying the impact of style of life on health]. Problemy sotsial'noi gigieny, zdravookhraneniya i istorii meditsiny, 2014, vol. 22, no. 2, pp. 39-42 (in Russian).

9. Galea S. Macrosocial determinants of population health. New York, Springer Publishing Company, 2007, 502 p. DOI: 10.1007/978-0-387-70812-6

10. Stuckler D. Population causes and consequences of leading chronic diseases: a comparative analysis of prevailing explanations. The Milbank quarterly, 2008, vol. 86, no. 2, pp. 273-326. DOI: 10.1111/j.1468-0009.2008.00522.x

11. Coleman J.S. Social capital in the creation of human capital. American journal of sociology. Supplement: Organizations and institutions: sociological and economic approaches to the analysis of social structure, 1988, vol. 94, pp. S95-S120. 
12. Putnam R.D. Bowling alone: America's declining social capital. Journal of democracy, 1995, vol. 6, no. 1, pp. 65-78. DOI: 10.1353/jod.1995.0002/

13. Bourdieu P. The forms of capital. Handbook of theory and research for the sociology of education. In: J.G. Richardson ed. New York, Greenwood Publ., 1986, pp. 241-258.

14. Putnam R.D., Leonardi R., Nanetti R. Making democracy work: civic traditions in modern Italy. Princeton, Princeton University Press Publ., 1993, 280 p.

15. Portes A. Social capital: its origins and applications in modern sociology. Annual review of sociology, 1998, no. 24, pp. 1-24. DOI: 10.1146/annurev.soc.24.1.1

16. Lin N. Building a network theory of social capital. Connections INSNA, 1999, vol. 22, no. 1, pp. $28-51$.

17. Gudkova T.V. Sotsial'nyi kapital kak faktor sotsiokul'turnogo i ekonomicheskogo razvitiya obshchestva [Social capital as a factor of socio-cultural and economic development of society]. Filosofiya khozyaistva, 2015, no. 2, pp. 197-204 (in Russian).

18. Tikhonova N.E. Sotsial'nyi kapital kak faktor neravenstva [Social capital as a factor of inequality]. Obshchestvennye nauki i sovremennost', 2004, no. 4, pp. 24-35 (in Russian).

19. Lin N. Social capital: a theory of structure and action. New York: Cambridge University Press, 2001, 294 p. DOI: 10.1017/CBO9780511815447

20. Putnam R.D. Bowling alone: the collapse and revival of American community. New York: Simon and Schuster, 2000, $541 \mathrm{p}$.

21. Block M., Golovin N.A. Sotsial'nyy kapital: k obobshcheniyu ponyatiya [Social capital: the generalization of the concept]. Vestnik Sankt-Peterburgskogo universiteta. Seriya 12: Psikhologiya. Sotsiologiya. Pedagogika, 2015, no. 4, pp. 99-111 (in Russian).

22. Fukuyama F. Velikii razryv [Great Gap]. In: A.V. Aleksandrova ed. Moscow, Izd-vo ACT Publ., 2004, 474 p. (in Russian).

23. Bykov I.A. Sotsial'nyy kapital i politika v Rossii: portret na fone Yevropy [Social capital and politics in Russia: a portrait against the backdrop of Europe]. Politicheskaya ekspertiza, 2011, no. 1, pp. 102-116 (in Russian).

24. Kozyreva P.M. Mezhlichnostnoye doveriye v kontekste formirovaniya sotsial'nogo kapitala [Interpersonal trust in the context of the formation of social capital]. Sotsiologicheskiye issledovaniya, 2009, vol. 297, no. 1, pp. 43-54 (in Russian).

25. Latov Yu. Kakov sotsial'nyy kapital sovremennoy Rossii? (sravnitel'nyy analiz mezhlichnostnogo i institutsional'nogo doveriya) [What is the social capital of modern Russia? (comparative analysis of interpersonal and institutional trust)]. Leont'yevskiye chteniya: Elektronnyy zhurnal, 2010, no. 7, pp. 216-230. Available at: http://uisrussia.msu.ru/docs/ nov/leontief /2010/Latov.pdf (09.09.2018) (in Russian).

26. Stebakov A.A. Metody izmereniya urovnya sotsial'nogo kapitala v Rossii i za rubezhom [Methods for measuring the level of social capital in Russia and abroad]. Izvestiya Saratovskogo universiteta. Novaya seriya. Seriya: Ekonomika. Upravleniye. Pravo, 2014, vol. 14, no. 2-2, pp. 430-436 (in Russian).

27. House J.S. Work stress and social support. Addison-Wesley Reading, Mass, 1981, 156 p.

28. Cohen S., Wills T.A. Stress, social support, and the buffering hypothesis. Psychological Bulletin, 1985, vol. 98 , no. 2 , pp. 310-357.

29. Uchino B.N., Carlisle M., Birmingham W., Vaughn A.A. Social support and the reactivity hypothesis: conceptual issues in examining the efficacy of received support during acute psychological stress. Biological psychology, 2011, vol. 86, no. 2, pp. 137-142. DOI: 10.1016/j. biopsycho.2010.04.003

30. Lifintseva A.A. Sotsial'naya podderzhka kak faktor preodoleniya negativnykh posledstviy stressa [Social support as a factor in overcoming the negative consequences of stress]. Vestnik Baltiyskogo federal'nogo universiteta im. I. Kanta. Seriya: Filologiya, pedagogika, psikhologiya, 2012, no. 5, pp. 56-61 (in Russian).

31. Egolf B., Lasker J., Wolf S., Potvin L. The Roseto Effect: a 50-year comparison of mortality rates. American journal of public health, 1992, vol. 82, no. 8, pp. 1089-1092. 
32. Berkman L.F., Glass T. Social integration, social networks, social support, and health: Social epidemiology. In: L.F. Berkman, I. Kawachi eds. New York, Oxford University Press Publ., 2000, pp. 137173.

33. Byusse S. Sotsial'nyy kapital i neformal'naya ekonomika v Rossii [Social Capital and the Informal Economy in Russia]. Mir Rossii, 2002, no. 2, pp. 93-104 (in Russian).

34. Marmot M. Status syndrome. How your social standing directly affects your health and life expectancy. London, Bloomsbury Publ., 2004, 311 p.

35. Eriksson M. Social capital and health: implications for health promotion. Global health action, 2011, vol. 4, no. 1, pp. 1-11. DOI: 10.3402/gha.v4i0.5611

36. Uphoff E.P., Pickett K.E., Cabieses B., Small N., Wright J. A systematic review of the relationships between social capital and socioeconomic inequalities in health: a contribution to understanding the psychosocial pathway of health inequalities. International journal for equity in health, 2013, vol. 12, no. 1, pp. 1-12. Available at: https://equityhealthj.biomedcentral.com/ articles/10.1186/1475-9276-12-54 (09.09.18).

37. Poortinga W. Do health behaviors mediate the association between social capital and health? Preventive medicine, 2006, vol. 43, no. 6, pp. 488-493. DOI: 10.1016/j.ypmed.2006.06.004

38. Lindström M., Hanson B.S., Ostergren P.O. Socioeconomic differences in leisure-time physical activity: the role of social participation and social capital in shaping health related behavior. Social science and medicine, 2001, vol. 52, no. 3, pp. 441-451.

39. Veenstra G. Social capital, SES and health: an individual-level analysis. Social science and medicine, 2000, vol. 50, no. 5, pp. 619-629.

40. Lucumi D., Gomez L.F., Brownson R.C. and Parra D. Social capital, socioeconomic status, and health-related quality of life among older adults in Bogotá (Colombia). Journal of aging and health, 2015, vol. 27, no. 4, pp. 730-750. DOI: 10.1177/0898264314556616

41. Altschuler A., Somkin C.P., Adler N.E. Local services and amenities, neighborhood social capital, and health. Social science and medicine, 2004, vol. 59, no. 6, pp. 1219-1229.

42. Gittell R., Vidal A. Community organizing. Building social capital as a development strategy. California, SAGE Publications Publ., 1998, 206 p.

43. Szreter S., Woolcock M. Health by association? Social capital, social theory, and the political economy of public health. International journal of epidemiology, 2004, vol. 33, no. 4, pp. 650-667.

44. Kawachi I., Berkman L.F. Neighborhoods and Health. New York, Oxford University Press Publ., 2003, 368 p.

45. Kawachi I., Kennedy B.P., Glass R. Social capital and self-rated health: a contextual analysis. American journal of public health, 1999, vol. 89, no. 8, pp. 1187-1193.

46. Villalonga-Olives E., Kawachi I. The dark side of social capital: a systematic review of the negative health effects of social capital. Social science and medicine, 2017, vol. 194, pp. 105-127.

47. Marsh C. Social capital and grassroots democracy in Russia's regions: evidence from the 19992001 gubernatorial elections. Demokratizatsiya: the journal of post-soviet democratization, 2002, vol. 10, no. 1 , pp. 19-36.

48. Vasil'eva E.N., Poltavskaya M.B. Ekonomicheskaya i sotsial'naya aktivnost' naseleniya kak indikator formirovaniya sotsial'nogo kapitala [Economic and social activity of population as an indicator of social capital formation]. Izvestiya VUZov. Povolzhskiy region. Obshchestvennyye nauki, 2015, vol. 36, no. 4, pp. 113-119 (in Russian).

49. Turner B. Social capital, inequality, and health: The durkheimian revival. Social theory and health, 2003, vol. 1, no. 1, pp. 4-20.

50. Kawachi I., Kennedy B.P., Lochner K. Long live community: social capital as public health. The American prospect, 1997, vol. 35, pp. 56-59.

51. De Silva M.J., Huttly S.R., Harpham T., Kenward M.G. Social capital and mental health: a comparative analysis of four low income countries. Social science and medicine, 2007, vol. 64, pp. 5-20.

52. Harpham T., Grant E., Thomas E. Measuring social capital within health surveys: key issues. Health policy and planning, 2002, vol. 17, no. 1, pp. 106-111. 
53. Rusinova N.L., Safronov V.V. Znacheniye sotsial'nogo kapitala dlya zdorov'ya v stranakh Yevropy [The importance of social capital for health in Europe]. Zhurnal sotsiologii $i$ sotsial'noy antropologii, 2014, no. 3, pp. 112-133 (in Russian).

54. Belov V.B., Rogovina A.G. Sotsial'nyy kapital i zdorov'ye naseleniya [Social capital and public health]. Problemy sotsial'noy gigiyeny, zdravookhraneniya i istorii meditsiny, 2013, pp. 3-5 (in Russian).

55. Karhina K., Ng N., Ghazinour M., Eriksson M. Gender differences in the association between cognitive social capital, self-rated health, and depressive symptoms: a comparative analysis of Sweden and Ukraine. International journal of mental health systems, 2016, vol. 10, no. 37, pp. 1-14. DOI 10.1186/s13033-016-0068-4

56. Iversen $\mathrm{T}$ An exploratory study of associations between social capital and self-assessed health in Norway. Health economics, policy, and law, 2008, vol. 3, pp. 349-364.

57. Rocco L, Suhrcke M. Is social capital good for health? A European perspective. Copenhagen. WHO Regional Office for Europe, 2012, 24 p.

Lebedeva-Nesevrya N.A., Eliseeva S.Yu. Social capital as a factor that contributes into population health: analytical review. Health Risk Analysis, 2018, no. 3, pp. 156-164. DOI: 10.21668/health.risk/2018.3.17.eng

Received: 12.08 .2018

Accepted: 21.09 .2018

Published: 30.09.2018 